\title{
Effects of Production and Market Innovations on the Level of Competitiveness of Sorghum Small Scale Agrienterprises
}

\author{
Kipchumba Judith ${ }^{*}$, Edith Gathungu1, Oscar Ingasia Ayuya1, Paul Kimurto² \\ ${ }^{1}$ Department of Agricultural Economics and Agribusiness Management, Egerton University, Njoro, Kenya \\ ${ }^{2}$ Department of Crops, Horticulture and Soils, Egerton University, Njoro, Kenya \\ Email: *judithjerop10@gmail.com
}

How to cite this paper: Judith, K., Gathungu, E., Ayuya, O. I., \& Kimurto, P. (2021). Effects of Production and Market Innovations on the Level of Competitiveness of Sorghum Small Scale Agrienterprises. Modern Economy, 12, 1137-1159.

https://doi.org/10.4236/me.2021.127060

Received: June 3, 2021

Accepted: July 23, 2021

Published: July 26, 2021

Copyright $\odot 2021$ by author(s) and Scientific Research Publishing Inc. This work is licensed under the Creative Commons Attribution International License (CC BY 4.0).

http://creativecommons.org/licenses/by/4.0/

\section{(c) (i) Open Access}

\begin{abstract}
Agricultural innovations are keys to economic growth, income stability as well as nutritional enhancement particularly in marginal areas since they are well-adapted to poor or unpredictable agro-ecological conditions. Innovation is a critical player that is seen to bring competitiveness, increase productivity and efficiency to agrienterprises. Despite that, there is limited empirical evidence on whether the uptake of the innovations has on sorghum competitiveness in small scale farm level agriprenuers in most ASALs of Eastern Kenya. This study examines the effect of production and market innovation on the competitiveness of sorghum agriprenuers, using primary data collected in 2019 from a total of 384 randomly selected small scale agrienterprises. A multivalued treatment effect model was applied to determine the role of innovation on the competitiveness of sorghum enterprises. Farm productivity and gross margin analysis were used to measure the competitiveness of the agrientreprises. The results indicated that gross margin and farm productivity of sorghum agrienterprises increase with an increase in the number of innovations used. These innovations include the uses of improved sorghum seeds, conservation agriculture, and group marketing. But also, there was a decrease in both gross margin and productivity for the agrienterprises with the highest number of innovations in the farm at saturation level. The results implied that the kind and the number of innovations employed in agrienterprises development are critical in its profitability and productivity. Therefore, interventions targeting usage of innovations in sorghum agrienterprises should be sensitized to integrate different innovations on product, process, and market in enhancing competitiveness.
\end{abstract}

\section{Keywords}

Product Innovation, Market Innovation, Competitiveness, Multivalued 
Treatment Effect, Small Scale Agrienterprises

\section{Introduction}

Agricultural development is fundamental for sustainable economic development and poverty alleviation in developing countries. It is also the primary source of food and a contributor to household economies. Agrienterprises hold a major share in the provision of raw materials for industries and the national economy (Dar \& Laxmipathi, 2013). Similarly, (Grebmer et al., 2010) maintain that income from agriculture is the major source of satisfaction in a nation's health and educational needs. Kenya's agriculture sector is important too in alleviating poverty, $60 \%$ of the population earn their livelihood from the sector and also contribute to $50 \%$ of the country's gross domestic product (GDP), about $65 \%$ of the export earnings, and $18 \%$ of the formal employment (GoK, 2017). Despite this, $53 \%$ of rural Kenyans live below the poverty line and $93 \%$ of them are located in arid and semi-arid lands (Titilola et al., 2018).

According to (Karimi et al., 2019), ASALs experience erratic rainfall, rough terrains, and nutrient-poor soils. In Kenya, ASALs occupy more than $80 \%$ of the country and are home to about 10 million people. The increase in population has led to the encroachment of these areas. Approximately $70 \%$ of the national livestock herd is found in these areas with vulnerabilities to food insecurity, climate variability and change is high (Orr et al., 2016). Besides, land degradation in the form of soil erosion and nutrient depletion poses a threat to the sustainability of agricultural production particularly in the ASALs (Ogada et al., 2010). Sorghum is one of the stapled crops in the rural ASALs of Kenya and the primary source of energy, protein, vitamins, and micronutrients (Orr et al., 2013), they are also considered as climate-smart crops with broad adaptation and resilience (Titilola et al., 2018). Therefore, sorghum can contribute to better food and nutritional security in this area than commonly produced cereals such as maize, wheat, and rice since they can grow well on marginal lands with poor soil fertility (Onyango, 2016).

Innovations are considered a critical player in the agriculture sector in the development of the country's economic growth (Esparcia, 2013). They are seen to bring about productivity, competitiveness, quality, and efficiency to farm agrienterprises (Mutsvangwa-Sammie et al., 2017). (Distanont \& Khongmalai, 2018) also added that innovation is key to increasing the capacity and creating a competitive advantage for small scale agriprenuers since they enable them to present a new or improved product to the market thus increasing their market share. According to (Aziz \& Samad, 2016), innovation is a strategy that enables agriprenuers to create long term competition by gathering knowledge, experiences in creating and developing agrienterprises, using skills in technology, and introducing new ideas in form of product innovation, market innovation, or business model in- 
novation. Moreover, Production and market innovations are crucial to increasing agricultural productivity for food security and income especially in developing countries (Godfray et al., 2010).

Market innovation through the use of technology is a resource-based advantage for agrienterprises to exchange knowledge and information on the opportunities available in the marketplace (Gupta et al., 2016). This exchange of field notes among agrienterprises, sellers and buyers, aid the search of unforeseen events and identification of innovative ideas to address chance opportunities. According to (Nenonen et al., 2019), the most likely way of agrienterprises improving their market creativities is by creating new marketing channels, reformulating the existing ones, ascertaining new managerial approaches, and developing new services, such as collective marketing and contracting farming by agrienterprises. (Lin et al., 2010) relates this market innovation to retailing channels, marketing information systems, market segmentation, market research, and price-setting strategy.

Moreover, sorghum has great potential as a food and cash crop. These crops are highly nutritious, drought-tolerant, high yielding, disease-tolerant, and have the ability to yield produce with little input use (Orr et al., 2016). Sorghum, for example, is a healthy food as research shows it prevents the growth of cancer cells, diabetes and helps to manage cholesterol in the body. Sorghum small grain has an extended shelf of several years without significant damage by storage pests, thus offers food security opportunities for the rural communities who are small scale farmers. It also has high nutritional benefits owing to its high nutritive content especially for pregnant women, nursing mothers and children, provides carbohydrates with a low glycaemic index with high soluble fibre, high calcium, diastolic power, and low fat of malted grains (Gamage et al., 2017).

According to (Carayannis \& Grigoroudis, 2016), the notion of innovation, productivity, and competitiveness are inherently linked. Hence, collective efforts must be enhanced to promote innovations in the production and utilization of sorghum and millet products, as both agrienterprises provide adequate rewards to small scale farmers while at the same time the consumers with high-quality food and feeds (Gupta et al., 2016). The fundamental role that agriculture plays in the Kenyan economy warrants policies to be designed regarding household food security and the type of crop to be produced by small scale farm agrienterprises, particularly in the marginal areas.

In Kenya, sorghum technologies that improve value chain efficiency, raise productivity and increase income in the Eastern region have been developed and deployed. These market-oriented innovations on production and outlet linkages of sorghum were designed to improve upstream and downstream points, upscaling, and development of small-scale farm agrienterprises in product markets, but farm's competitiveness is low in ASALs. Although there is evidence of combined efforts in the application of these innovations, little information is available on the role of farmer innovative capability, socioeconomic and institutional characteristics in the uptake of the innovations. Further, there is limited empiri- 
cal evidence on whether the uptake of the innovations has on sorghum competitiveness in small scale farm level agriprenuers in most ASALs of Eastern Kenya. It is on the foregoing that this study aims to fill this knowledge gap among small scale agrienterprises in Tharaka Nithi County, Kenya.

\section{Methodology}

\subsection{Study Area}

This study was undertaken in Tharaka Nith County, Kenya. The County lies at the feet of Mt Kenya, covering approximately $266,201 \mathrm{~km}^{2}$, including Mt Kenya forest which is estimated at $360 \mathrm{~km}^{2}$ with a population of approximately 363,177 people comprising of male $49.3 \%$ and female $50.7 \%$ (KNBS, 2019). The County borders Meru to the North and North East, Kitui to the East and South East, Embu to the South and South West, Kirinyaga and Nyeri to the West. The County lies between longitude $37^{\circ} 19^{\prime}$ and $37^{\circ} 46^{\prime}$ East and between latitude 000 $07^{\prime}$ and $00026^{\prime}$ South. The county receives bimodal and unreliable annual rainfall with an average of between $200 \mathrm{~mm}$ and $800 \mathrm{~mm}$, but most parts of the county receiving less than $750 \mathrm{~mm}$ yearly. The area was selected because of its high potential in sorghum production. Also, due to the presence of government and other stakeholders' intervention in promoting sorghum production and agrienterprises competitiveness, it is help to improve the smallholder livelihoods through the use of innovations.

\subsection{Sampling Produce}

A multistage sampling procedure was used to obtain 384 small scale farm agrienterprises to participate in the survey. The first stage involved a purposive selection of the Tharaka North and South sub-county due to its conducive ecological zone for sorghum production and also there are existences of various initiatives in the promoting production and use of underutilized crops to improve the livelihoods of the residents. The second stage involved a purposive selection of two wards, one from each sub-county, with the most extensive projects on sorghum production. The third stage was the random selection of villages. Finally, a simple random selection of 384 sorghum small scale farm agrienterprises was selected from the villages.

\subsection{Sample Size Determination}

The required sample size of sorghum small scale agrienterprises was determined by (Ahmad \& Halim, 2017) formula.

where,

$$
n=\frac{Z^{2} p q}{E^{2}}
$$

$n=$ the desired sample size;

$Z=$ the standard deviation set using the desired confidence level (at $95 \%$ confidence level $Z$ is 1.96); 
$p=$ proportion of the target population containing the major interest;

$q=1-p$ and

$E=$ the degree of accuracy desired in the study is $95 \%$.

$$
n=\frac{1.96^{2} \times 0.5 \times(1-0.5)}{0.05^{2}}=384
$$

\subsection{Analytical Framework}

The interest of the study lies in the causal effect of production and market innovation on the competitiveness of sorghum agrienterprises. Multiple treatments have no true counterfactual, hence it possible to estimated pairwise treatment between the different treatment units production " $p$ " (production innovation) and " $m$ " (market innovation) (Lechner, 2001). Hence the outcomes include:

1) The average treatment effect of the treatment $p$ relative to treatment $m$,

$$
\tau^{p m}=\mathrm{E}\left[Y_{i p}-Y_{i m}\right]=\mu_{p}-\mu_{m} .
$$

2) The average treatment effect for an agrienterprise from among the treatment group, $p$

$$
\gamma^{p m / p}=\mathrm{E}\left[Y_{i p}-Y_{i m} / T_{m}=m\right]=\mu_{p / p}-\mu_{m / p} .
$$

3) The symmetric treatment effect for the other treatment level $m$, that is, the average treatment of treated (ATT) with respect to treatment $m$,

$$
\tau^{p / m}=-\tau^{m / p} .
$$

4) The average treatment effect (ATE) of treatment " $p$ " with respect to treatment $m$ ' on the subpopulation of the unit under treatment " $m$ " is:

$$
-\tau^{m p / m} \text {. }
$$

The potential outcome assumption framework for the binary treatment unit was re-expressed to multiple treatment units. Thus, the condition independence (CIA) assumption and overlap form the basis for causal effect estimation in this model, extended as the general propensity score (GPS). The GPS is the positive probability of receiving a treatment level given the condition variable (Adeyemo et al., 2018),

$$
r(t, x)=\operatorname{Pr}\left[T_{I}=t \mid X_{I}=x\right]=\mathrm{E}\left[D_{i t}\left(T_{i}\right) \mid X_{i}=x\right] .
$$

From (Funk et al., 2011) the potential outcome means can, therefore, be determined by weighting the observed outcome of the treatment with the estimated GPS weights given as

$$
\mathrm{E}\left(Y_{i t}\right)=\left[\frac{Y_{i} D_{i t}\left(T_{i}\right)}{r\left(t, X_{i}\right)}\right]
$$

where $r\left(t, X_{i}\right)>0$.

The overlap assumption was taken into consideration with condition independences to form strong Ignorability (Zhang et al., 2021), which is complete overlap in the distribution of covariance between the treatment levels (Linden et 
al., 2016). Established from the notation assumption, there are approaches to estimating treatment effects in multivalued. This included Regression Adjustment (RA) estimator, Inverse Probability weighting (IPW) and doubly robust estimators (DRE).

The RA estimators are used in case of weak unconfounded, the regression model was used to calculate the potential outcome after adjusting the $X_{i}$ covariates which are assumed to have the confounders in the study the make inference unbiased. The RA fits separate lines for regression function for users and non-users, with different effects on profitability and productivity.

Since from RA, we cannot only use the sampled mean profits and productivity of the agrienterprises output on innovation users and non-users to estimate the effect of innovation on the agrienterprises competitiveness. IPW is a treatment-effect estimator that applies the use of a weighted average instead of an unweighted average to separate the effects of the treatment on other confounders like level of education. The probabilities are attained by fitting a model of treatment status on the characteristics of each theme. Hence the utility of IPW was dependent on how the treatment model predicts the probability of the treatment. IPW has limited to positive probabilities only also the overlap concept and because it uses weighted means to obtain potential outcome means (POMs) and ATE.

The DRE includes the augmented inverse probability weighted (AIPW) estimators and the inverse probability weighted regression adjustment (IPWRA) estimator. These two estimators combine elements of the RA and IPW estimators to be more robust to misspecifications.

The AIPW estimator combines IPW with augmentation term that helps to correct treatment model misspecification. Like IPW, AIPW does not work well when the predicted treatment probabilities are near zero or one (Linden et al., 2016).

The IPRWA estimator is an RA estimator that uses estimated inverse probability weights to correct the estimator when the regression model is misspecified. When the model is correctly specified, the weight does not affect the consistency of the estimator.

The multivariate treatment effect mode specification to estimate the joint effects among different production and market innovations can be written as (Linden et al., 2016);

$$
\operatorname{Prob}\left(y_{i}=1 \mid t_{i}, x_{i}\right)=\Lambda\left(t_{A i} \gamma_{A}+t_{B i} \gamma_{B}+t_{A i} t_{B i} \gamma_{A B}+x_{i} \beta\right) .
$$

$y_{i}$-represent the effect of production and market innovations on the competitiveness of an agrienterprises;

$t_{A i}$ represents production innovation used by the agrienterprises;

$t_{B i}$ represents market innovation used by the agrienterprises;

$x_{i}$ represents the list of control variables;

$\gamma_{A}$ is the independent treatment effect of production innovation;

$\gamma_{B}$ is the independent treatment effect of market innovation; 
$\gamma_{A B}$ is the interaction treatment of production and market innovation;

$\beta$ is the regression coefficient for each of the control.

\section{Results and Discussion}

\subsection{Agrienterprises and Sorghum Agriprenuers Characteristics}

\subsubsection{Innovations Used in Sorghum Agrienterprises}

The competitiveness of agrienterprises was measured using a log of gross margin and productivity of the agrienterprises. The number of innovations adopted was used as the treatment units $(t)$ which were 5 levels, with $t=0,1,2,3$, 4 ; representing non-user of innovation, Low-level innovation users, middle-level innovation users, high-level innovation users and very high-level innovation users respectively. The results showed that $20 \%$ of the respondents were non-users, $41 \%$ are low-level users, $25 \%$ were middle-level innovation users, $7 \%$ for both high and very high-level users of innovations as presented in Table 1 . There were several innovations promoted by the ministry of agriculture, livestock and fishery as well as NGOs in the county. However, the results show that the majority (41\%) of sorghum agrienterprises used at least one innovation on their farm. Therefore, cumulatively low uptake of the number of innovations used.

Table 1. Composition of sorghum agrienterprises innovation users.

\begin{tabular}{cccc}
\hline Variable & Description & Frequencies & Percentages \\
\hline & Non-users & 77 & 20 \\
Lnnovations Users & Low-level users & 156 & 41 \\
& Middle-level Users & 96 & 25 \\
& High-level users & 27 & 7 \\
& Very high-level Users & 28 & 7 \\
Total & & 384 & 100 \\
\hline
\end{tabular}

\subsubsection{Socio-Economic Characteristics of Sorghum Agrienterprises}

Table 2 presents the results of mean age, schooling years, years of experiences and sorghum agriprenuers' farm size. The average age of all sample sorghum agriprenuers users was 43 years same as innovation users while the mean age of non-users was 44 years. The association between users' age and innovation non-users age was statistically significant at $10 \%$. The sorghum innovation users' age was slightly older by 1 year with their counterparts.

This implies that older sorghum tends to have more experiences in sorghum farming and over the years they have experimented on different innovations introduced in the region, hence they can conclusively apply innovations that worked well for them. Nevertheless, the age of sorghum agriprenuers in the study area was within the age categorized as active and productive (Mmbando \& Baiyegunhi, 2016).

The average years of schooling for all sampled sorghum agrienterprises were 9 
Table 2. Mean age, schooling years, years of experiences and sorghum agriprenuers' farm size.

\begin{tabular}{ccccccc}
\hline & \multicolumn{2}{c}{ Users } & \multicolumn{2}{c}{ None Users } & & \\
\hline Variable & Mean & $\begin{array}{c}\text { Std. } \\
\text { Error }\end{array}$ & Mean & $\begin{array}{c}\text { Std. } \\
\text { Error }\end{array}$ & $\begin{array}{c}\text { Overall } \\
\text { mean }\end{array}$ & t-value \\
Age & 42.75 & 0.68 & 43.86 & 1.69 & 42.97 & $-0.694^{*}$ \\
Schooling years & 9.64 & 0.29 & 7.94 & 0.60 & 9.30 & $2.638^{* *}$ \\
Years of experiences & 8.55 & 0.49 & 12.78 & 1.57 & 9.41 & $-3.41^{* * *}$ \\
Farm size (acres) & 3.44 & 0.13 & 2.59 & 0.21 & 3.28 & $2.97^{* *}$ \\
$\begin{array}{c}\text { Distances to the } \\
\text { nearest market }(\mathrm{km})\end{array}$ & 1.57 & 0.08 & 1.35 & 0.21 & 1.54 & $1.039^{*}$ \\
\hline
\end{tabular}

Note: ${ }^{* * *},{ }^{* *},{ }^{*}$ imply significant at $1 \%, 5 \%$ and $10 \%$ level respectively. Std. Error stands for standard Error.

years whereas that of innovation users was 10 years and non-users of innovations was 8 years. The differences in years of schooling between users and nonusers of innovation were significant at $5 \%$. Users of innovation have slightly more years of schooling as compared to their counterparts. This implies that more years of education, exposures sorghum agriprenuers to several different innovations, their application and their benefits. Through this, agriprenuers can use the innovations exposed to effectively. The results concurred with several studies suggest that educated agriprenuers are alleged to have a higher capability to attain, infer and respond to information on available innovations. (Jerop et al., 2018) found that educated agriprenuers are more likely to access information and guidance from extension providers which influence their usage of innovations.

The sorghum agriprenuers' years of experiences were 9 years. Users of innovations had 8 years of experiences which is less than 12 years of experiences of non-users of innovations. The t-test results nevertheless show that the variance in years of experience between users and non-users was significant at $1 \%$. This implies that non-users tend to be inflexible to innovations having been adopted earlier than users. This result is in line with studies such as that of (Wabwile et al., 2016) in the effect of improved sweet potatoes varieties on household food security.

All sample sorghum agrienterprises had an average farm size of 3.3 acres. However, users had a relatedly big size of 3.4 acres as compared to non-users who had an average of 3 acres. There was a significant difference in farm size at $5 \%$. The users had relatively large farm sizes possibly because they are able to devote part of them of piece land to try various innovations in their farms as compared to their counterparts who have relatively small pieces of farm size. The land is a critical factor of production to sorghum agriprenuers. (Donkor et al., 2018) found that agriprenuers with large farm size can use more innovations especially the capital-intensive innovations.

The distance to the nearest market covered by users of innovation is approximately $1.6 \mathrm{~km}$ while non-users is $1.4 \mathrm{~km}$. The association between users and 
non-users was significantly different at $10 \%$. This was intriguing since the distance covered by the user of innovation was slightly longer than what is covered by their counterpart. Distance from the farm gate to the next-door market is considered a key factor for accessing the market and also the condition of the road, thus a measure of operation cost (Wabwile et al., 2016). Also, the location from the trading center is key since it plays a role of proxy for a potential market of farm inputs including outputs and vital information access on innovations to use in the agrienterprises. Despite this, there are possibilities that the users of innovation are primarily interested in better price thus profits for their quality and quantity produce, hence they could cover more distance to achieve it. Furthermore, possibly they would prefer to transport their produce to EABL agents rather than selling it at the farm gate to brokers.

\subsubsection{Institutional Characteristics of Sorghum Agriprenuers}

Table 3 present the results of the access to market information, group participation, access to credit, the number of training attended, number of extension services and contract arrangement. The users of innovation who had information on market and innovations were $75 \%$ while that of non-users was $56 \%$. The t-test results indicated that there was a significant difference between the user of innovation and non-users at a 5\% level. The results indicate that users of innovation tend to be more inquisitive on the market behaviours, as this information could enlighten their decision of the number of innovations to invest in to achieve market demands. In addition, the sorghum agriprenuers who uses innovations accessed more information on market prices of inputs, outputs, reliable buyers, issues of innovation more than non-users of innovations. Market information is key to every agriprenuers as it helps in developing, assessing and even monitoring the progress of the agrienterprises (Okello, 2017).

Group participation enriches idea and information exchange, social capital

Table 3. Access to market information, group participation, access to credit, number of training attended, number of extension services and contract arrangement.

\begin{tabular}{ccccc}
\hline & \multicolumn{4}{c}{ Innovation } \\
\hline Variable & Description & Users & None Users & Ch $^{2}$ Value \\
\hline \multirow{2}{*}{ Access to information } & Yes & 74.27 & 55.84 & $10.061^{* *}$ \\
& No & 25.73 & 44.16 & \\
Group participation & Yes & 51.14 & 16.88 & $29.282^{* * *}$ \\
Access to credit & No & 48.86 & 83.12 & \\
& Yes & 15.31 & 6.49 & $4.087^{* *}$ \\
Contract arrangement & No & 84.69 & 93.51 & \\
& Yes & 6.51 & 2.60 & 1.749 \\
& No & 93.49 & 97.40 &
\end{tabular}

Note: ${ }^{* *},{ }^{* *},{ }^{*}$ imply significant at $1 \%, 5 \%$ and $10 \%$ level respectively. 
allowing trust, resource mobilization and hence contribute positively and significantly to the uptake of innovations (Mwangi \& Kariuki, 2015). Over half of the innovation users (51\%) sampled, belonged to a group in contrast to $17 \%$ of the non-users. The relationship between the use of innovation and group participation was statistically significant at $1 \%$. Hence it is evident that the use of production and market innovations in the agrienterprises is influenced by group membership. Group simply unite and help farmers obtain information or training on diverse agriculture innovations issues (Wabwile et al., 2016) that influence the use of the innovation given to improve their farm performances.

Access to credit services is a former implement in the development of any agripreneurial venture and thus stimulates growth. Of the users, $15 \%$ had accessed credit whereas $85 \%$ had no access to credit. It is evident that users accessed credit for more than non-users. The association between the users and non-users of innovation is statically significant at $5 \%$. Credit access by agrienterprises promotes the use of risky innovations through relaxation of the liquidity constraint as an option of borrowing. With the availability of credit, sorghum agriprenuers have a better capacity to invest in various innovations. Credit also enables agriprenuers to purchase farm inputs improved sorghum seeds, agrochemicals, hire extra labour hence improve the farm's competitiveness (Gaiha \& Mathur, 2019).

\subsubsection{Farmer's Innovative Capabilities}

Table 4 presented the results of Confirmatory Factor Analysis (CFA), which included factor loading, Cronbach alpha, Average Variance Extracted (AVE) and Kaiser-Meyer-Olkin (KMO) measure of sample adequacy. Five latent constructs were used to categorize farmers' innovative capabilities into product innovativeness, product innovativeness, strategic innovativeness, market innovativeness and behavioural innovativeness. A Likert scale was used to rank the descriptions to define weighted scores. The scale ran from $1-5$ for the description's measurement (where 1 meant strongly disagree and 5 meant strongly agree). Kaiser's criterion for the determination of factors to retain was adopted. The factor loading documented values between 0.654 and 0.885 at a significance level of $p=0.000$. The factor loading values were above 0.5 , hence justifiable enough to establish the least loading necessary to comprise construct (Sen \& Antara, 2018).

Cronbach alpha values were assessed to measure internal consistency reliability (CR). The alpha for the constructs documented values between 0.721 and 0.896 which demonstrated satisfactory indicators for reliability and convergent validity of the constructs (Gandhi et al., 2019). All the latent variable recorded AVE values between 0.625 and 0.779 were above 0.5 thresholds, showing that each construct was highly related to its respective apart from product innovativeness with AVE of 0.454 . The weak AVE value of product innovativeness is relieved by its CR of 0.75 and KMO of 0.756 which meets the threshold as recommended by (Adegbembo et al., 2020). KMO values for product innovativeness, process, 
Table 4. Factor analysis of innovative capabilities.

\begin{tabular}{|c|c|c|c|c|c|}
\hline Variable & Items & $\begin{array}{l}\text { Factor } \\
\text { Loading }\end{array}$ & CR & AVE & KMO \\
\hline \multirow{5}{*}{$\begin{array}{l}\text { Production } \\
\text { innovativeness } \\
\text { (Bhupendra \& } \\
\text { Sangle, 2015) }\end{array}$} & $\begin{array}{l}\text { My agrienterprises' new products } \\
\text { are often considered as very } \\
\text { unique by customers }\end{array}$ & 0.657 & 0.750 & 0.454 & 0.756 \\
\hline & $\begin{array}{l}\text { My agrienterprises develop } \\
\text { new product/service }\end{array}$ & 0.654 & & & \\
\hline & $\begin{array}{l}\text { In comparison to the competition, } \\
\text { my agrienterprises have introduced } \\
\text { more innovations in the past } 5 \text { years }\end{array}$ & 0.663 & & & \\
\hline & $\begin{array}{l}\text { My agrienterprises' recent new } \\
\text { product is significantly different } \\
\text { from previous productions }\end{array}$ & 0.772 & & & \\
\hline & $\begin{array}{l}\text { In comparison to the competition, } \\
\text { my agrienterprises' production } \\
\text { is successful }\end{array}$ & 0.815 & & & \\
\hline \multirow{5}{*}{$\begin{array}{l}\text { Process } \\
\text { innovativeness } \\
\text { (Bhupendra \& } \\
\text { Sangle, 2015) }\end{array}$} & $\begin{array}{l}\text { My agrienterprises have flexible } \\
\text { production methods which can be } \\
\text { changed efficiently }\end{array}$ & 0.844 & 0.873 & 0.754 & 0.862 \\
\hline & $\begin{array}{l}\text { My agrienterprises has focused on } \\
\text { smart business processes upstage }\end{array}$ & 0.863 & & & \\
\hline & $\begin{array}{l}\text { My agrienterprises uses new delivery } \\
\text { and distribution network }\end{array}$ & 0.810 & & & \\
\hline & $\begin{array}{l}\text { My agrienterprises invest in new } \\
\text { techniques/equipment to } \\
\text { improve its activities }\end{array}$ & 0.778 & & & \\
\hline & $\begin{array}{l}\text { In the last } 2 \text { years, my agrienterprises' } \\
\text { production method is better }\end{array}$ & 0.778 & & & \\
\hline \multirow{2}{*}{$\begin{array}{l}\text { Strategic } \\
\text { innovativeness } \\
\text { (Bhupendra \& } \\
\text { Sangle, 2015) }\end{array}$} & $\begin{array}{l}\text { My agrienterprises have a good } \\
\text { range of product grades to } \\
\text { suit the customer choice }\end{array}$ & 0.885 & 0.721 & 0.681 & 0.500 \\
\hline & $\begin{array}{l}\text { In my agrienterprises, Key decision } \\
\text { maker has abilities to simulate } \\
\text { future market }\end{array}$ & 0.885 & & & \\
\hline \multirow{4}{*}{$\begin{array}{l}\text { Market } \\
\text { innovativeness } \\
\text { (Bhupendra \& } \\
\text { Sangle, 2015) }\end{array}$} & $\begin{array}{l}\text { New variety produce in my } \\
\text { agrienterprises often take up } \\
\text { against new competition }\end{array}$ & 0.830 & 0.896 & 0.779 & 0.882 \\
\hline & $\begin{array}{l}\text { My agrienterprises marketing } \\
\text { strategies are considered effective }\end{array}$ & 0.849 & & & \\
\hline & $\begin{array}{l}\text { My agrienterprises involves its } \\
\text { market partners when placing a } \\
\text { new product in the market }\end{array}$ & 0.825 & & & \\
\hline & $\begin{array}{l}\text { My agrienterprises produce products } \\
\text { that address customer needs }\end{array}$ & 0.844 & & & \\
\hline
\end{tabular}




\begin{tabular}{|c|c|c|c|c|c|}
\hline & $\begin{array}{l}\text { My agrienterprises explore } \\
\text { new market avenues }\end{array}$ & 0.859 & & \multirow{4}{*}{0.625} & \multirow{4}{*}{0.500} \\
\hline \multirow{3}{*}{$\begin{array}{l}\text { Behavioural } \\
\text { innovativeness } \\
\text { (Bhupendra \& } \\
\text { Sangle, 2015) }\end{array}$} & $\begin{array}{l}\text { In my agrienterprises, while } \\
\text { employing, ability to innovate } \\
\text { is critically evaluated }\end{array}$ & 0.851 & 0.728 & & \\
\hline & $\begin{array}{l}\text { My agrienterprises has a structured } \\
\text { process to approve new ideas for } \\
\text { implementation }\end{array}$ & 0.840 & & & \\
\hline & $\begin{array}{l}\text { Innovative behaviours are } \\
\text { rewarded often }\end{array}$ & 0.735 & & & \\
\hline
\end{tabular}

Note: chi-square; $d f$ p-value $=0.000 ;$ CR: composite reliability; AVE: average variance extracted; KMO: Kaisaer-Meiyer-Olkin.

strategic, market and behavioural innovativeness were 0.756, 0.862, 0.500, 0.882 and 0.500 respectively. From KMO values, the overall adequacy of product innovativeness was middling, process and market innovativeness were meritorious and strategic and behavioural were unacceptable (Gandhi et al., 2019). Therefore, for this study strategic innovativeness and behavioural innovativeness were dropped, product innovativeness, process innovativeness and market innovativeness were used.

The weighted mean of the farmer's innovative capabilities is presented in $\mathrm{Ta}$ ble 5. The Weighted Mean was used to engender the scores of products, innovativeness, process innovativeness, strategic innovativeness, market innovativeness and behavioural innovativeness. The t-test statics was used to compare the weighted means of the users and non-users of innovations.

As indicated in Table 5, farmers' product innovativeness, process and market innovativeness were all significantly different between users and non-users at a $1 \%$ significant level. The means score of users were as high as compared to non-users this shows that the innovative capabilities of a key aspect in the competitiveness of an agrienterprises. Innovative capabilities are a core skill for agrienterprises that help to attain competitive advantage. Innovativeness refers to the degree to which a farmer is responsive to innovations promoted or new ideas and decides to apply them (Singh, et al., 2020). According to (Olsson et al., 2010) describe an agrienterprises' innovative capability as the ability to develop innovations continuously as a response to a changing environment, hence sustainability of the agrienterprises. Hence, an increase in the innovativeness of agripreneurs is viewed to be a key enabler to develop value and respond to the market as well as customer needs and demand, thus allow achieve suitable farm performances (Bamgbade et al., 2017).

However, the innovative capabilities discussed in this study include product innovativeness, process innovativeness and market innovativeness. Product innovativeness refers to the uniqueness of a new product being introduced to the market in an apt time (Bamgbade et al., 2017). Product innovativeness is informed by the market demand for a new product or new form of an 
Table 5. Mean score of farmer's innovative capabilities.

\begin{tabular}{cccc}
\hline Variables & Users & Non-users & t-test value \\
\hline Product innovativeness & 3.58 & 3.03 & $5.85^{\star * *}$ \\
Process innovativeness & 3.61 & 3.04 & $4.92^{\star * *}$ \\
Market innovativeness & 3.60 & 3.07 & $4.53^{\star * *}$ \\
\hline
\end{tabular}

Note: ${ }^{* *}$, significant at $1 \%$.

already existing product. Innovativeness in sorghum agrienterprises is more on producing newly introduced varieties to the market, the improved sorghum varieties developed by researchers. Such products tend to have relatively better attributes in terms of productivity, resistance to pest and disease and a have a high demand for seed as while as the produce.

On the other hand, process innovativeness refers to the propensity and capacity of sorghum agrienterprises to be innovative in their production process to deliver quality and quantity production and attain a competitive edge within the market (Bamgbade et al., 2017). It allows small-scale agriprenuers to meet the market demands in different ways, as it needs to understand the customers' needs and minimize loss from rejects. Some of the process innovations used include the use of good agronomic practices, conservation agriculture practices that enables agrienterprises to produce high volumes of agriculture produce to meet the buyers' demand like the malting company EBL, which buys sorghum in tons.

Market innovativeness is the new tactic to explore new market opportunities and exploit the existing market channels available (Bhupendra \& Sangle, 2015). Market innovation is also linked to product innovativeness since it also involves introducing a new product to the market. At the enterprises, increase market innovativeness enables the enterprises to be more aware of the new opportunities for better farm performance through the use of market channels (Micheels \& Gow, 2015). The ultimate goal of every agripreneur is to maximize profit either by reducing the cost of production or accessing a better market or price for their produce. An example of market innovativeness is contract farming. The contract arrangement between small-scale sorghum agrienterprises assures the market for the agriprenuers. It motivates a farmer to invest, produce quality and quantity produce since the prices are pre-determined and the market is readily available hence specified. Thus, the integration of innovative capabilities in agrienterprises is vital in the quest to realizing the competitiveness of the farm.

\subsection{Preliminary Diagnostic of the Variables to Be Used in Econometric Analysis}

Preliminary diagnostic for statistical problems of multicollinearity and heteroskedastic were conducted to the explanatory variables used in the econometric analysis. A white test was used to ascertain heteroscedasticity and results were presented in Table 6 . The results displayed presences of heteroskedasticity as a 
Table 6. White test results for heteroskedasticity.

\begin{tabular}{cccc}
\hline Source & ch' & Df & p-values \\
\hline Heteroskedasticity & 154.94 & 131 & 0.5191 \\
Skewness & 18.96 & 15 & 0.1180 \\
Kurtosis & 2.39 & 1 & 0.2138 \\
Total & 176.29 & 147 & 0.0871 \\
\hline
\end{tabular}

chi-square of 154.94 is significantly very large. This shows that the error term does not have a constant variance, hence to deal with this problem, the robust standard error was used in all econometric analyses.

Multicollinearity occurs when their high inter-correlation between independent variables, this was tested using pairwise correlation for categorical data and Variance inflation factor (VIF) for continuous variables. The results of the categorical variables are presented in Table 7 . The results indicated that there is no serious linear relationship among the categorical variables since the pairwise correlation coefficients were less than 0.75 .

For continuous variables, the results are presented in Table 8. In the same way, the results confirmed that there is no serious linear relationship between continuous variable as the VIF values were less than 10 .

\subsection{Role of Production and Market Innovations on the Level of Competitiveness of Sorghum Small Scale Agriprenuers}

To determine the role of production and market on the competitiveness of the sorghum agrienterprises Multivalued Treatment Effect (MTE) was used based on the assumptions of strong ignorability. Overlap assumption is graphically represented as the estimated probabilities of being assigned to a treatment unit (Appendix 1). The density illustrates that none of the treatment units has estimated probabilities at the extreme ends. The study, therefore, ascertains that the date gives unbiased inferences on the parameters of the treatment effects model estimated.

Competitiveness of agrienterprises was measured using the log of gross margin and productivity of the agrienterprises. The number of innovations used was used as the treatment units $(t)$ which were 5 levels, with $t=0,1,2,3$, 4; representing non-user of innovation, Low-level innovation users, middle-level innovation users, high-level innovation users and very high-level innovation users respectively The results showed that $20 \%$ of the respondents were non-users, $41 \%$ are low-level users, $25 \%$ were middle level innovation users, $7 \%$ for both high and very high-level users of innovations as presented in Table 9. There were a number of innovations promoted by the ministry of agriculture, livestock and fishery as well as NGOs in the county. However, the results show that majority (41\%) of sorghum agrienterprises used at least one innovation on their farm. Therefore, cumulatively low uptake of the number of innovations used. 
Table 7. Pairwise correlation of categorical variables.

\begin{tabular}{cccccc}
\hline & Gender & $\begin{array}{c}\text { Market } \\
\text { information }\end{array}$ & $\begin{array}{c}\text { Group } \\
\text { participation }\end{array}$ & $\begin{array}{c}\text { credit } \\
\text { facility }\end{array}$ & $\begin{array}{c}\text { Contract } \\
\text { arrangement }\end{array}$ \\
\hline Gender & 1 & & & & \\
Market information & -0.004 & 1 & & & \\
Group participation & -0.052 & 0.127 & 1 & & \\
credit facility & 0.051 & 0.022 & 0.199 & 1 & 1 \\
Contract agreement & 0.042 & 0.085 & 0.164 & 0.099 & 1 \\
\hline
\end{tabular}

Table 8. Variance inflation factor test results for multicollinearity.

\begin{tabular}{ccc}
\hline Variable & VIF & $1 /$ VIF \\
\hline Age & 1.76 & 0.568 \\
Household size & 1.24 & 0.808 \\
Years of schooling of the respondent & 1.39 & 0.720 \\
Years of experiences & 1.30 & 0.767 \\
Share of farm business & 1.46 & 0.683 \\
Market distances & 1.06 & 0.947 \\
Average farm gate price of sorghum & 1.09 & 0.920 \\
Product innovativeness & 2.91 & 0.344 \\
Process innovativeness & 3.69 & 0.271 \\
Market innovativeness & 3.90 & 0.257 \\
Mean & 1.98 & \\
\hline
\end{tabular}

Table 9. Composition of sorghum agrienterprises innovation users.

\begin{tabular}{cccc}
\hline Variable & Description & Frequencies & Percentages \\
\hline \multirow{2}{*}{ Innovations Users } & Non-users & 77 & 20 \\
& Low-level users & 156 & 41 \\
& Middle-level Users & 96 & 25 \\
& High-level users & 27 & 7 \\
Total & Very high-level Users & 28 & 7 \\
\hline
\end{tabular}

\subsubsection{Mean Potential Outcome across the Treatment Effects}

Estimates of potential outcome means (POM) of the log of gross margin for each of the treatment level across the treatment effects (number of innovations) estimator used are presented in Table 10. The estimators across each level were found to be significant at a $1 \%$ significant level. RA estimators are said to be constrained by the specification of correct function forms (Adeyemo et al., 2018) the estimator is the same as AIPW. However, IPW's violation of the overlap assumption chiefs biased estimates. Using the estimators from IPWRA, the potential 
Table 10. Potential outcome means of the log of gross margin and farm productivity across treatment used and estimators.

\begin{tabular}{|c|c|c|c|c|}
\hline \multirow[t]{2}{*}{ Estimator/Treatment unit } & \multicolumn{2}{|c|}{ Log Gross Margin } & \multicolumn{2}{|c|}{ Farm productivity } \\
\hline & Parameter & RSE & Parameter & RSE \\
\hline \multicolumn{5}{|l|}{$R A$} \\
\hline Non-Users & $9.184^{* * *}$ & 0.154 & $871.95^{\star * *}$ & 88.760 \\
\hline Low level Users & $9.404^{* * *}$ & 0.066 & $983.12^{* * *}$ & 71.803 \\
\hline Mid-level Users & $9.545^{\star * *}$ & 0.078 & $1263.19^{* * *}$ & 103.818 \\
\hline High level Users & $10.863^{* * *}$ & 0.119 & $1468.65^{* * *}$ & 122.236 \\
\hline Very high-level Users & $12.576^{\star * *}$ & 0.946 & $1396.81^{\star * *}$ & 311.933 \\
\hline \multicolumn{5}{|l|}{ IPW } \\
\hline Non-Users & $9.310^{* * *}$ & 0.107 & $910.54^{* * *}$ & 86.241 \\
\hline Low level Users & $9.422^{* * *}$ & 0.075 & $1000.79^{* * *}$ & 72.363 \\
\hline Mid-level Users & $9.599^{* * *}$ & 0.082 & $1237.55^{* * *}$ & 88.960 \\
\hline High level Users & $10.406^{* * *}$ & 0.131 & $1655.43^{* * *}$ & 125.170 \\
\hline Very high-level Users & $10.246^{* * *}$ & 0.070 & $1466.336^{* * *}$ & 86.063 \\
\hline \multicolumn{5}{|l|}{$I P W R A$} \\
\hline Non-Users & $9.307^{* * *}$ & 0.169 & $844.96^{\star * *}$ & 80.618 \\
\hline Low level Users & $9.403^{* * *}$ & 0.065 & $989.17^{* * *}$ & 73.330 \\
\hline Mid-level Users & $9.542^{\star * *}$ & 0.077 & $1264.94^{* * *}$ & 109.514 \\
\hline High level Users & $10.974^{* * *}$ & 0.167 & $1673.87^{* * *}$ & 303.153 \\
\hline Very high-level Users & $13.201^{\star * *}$ & 1.276 & $1493.32^{\star * \star}$ & 349.339 \\
\hline \multicolumn{5}{|l|}{$A I P W$} \\
\hline Non-Users & $9.184^{* * *}$ & 0.154 & $871.95^{\star * *}$ & 88.760 \\
\hline Low-level Users & $9.404^{\star * *}$ & 0066 & $983.12^{\star * *}$ & 71.803 \\
\hline Mid-level Users & $9.545^{\star * *}$ & 0.078 & $1263.19^{* * *}$ & 103.818 \\
\hline High level Users & $10.863^{\star * *}$ & 0.119 & $1468.65^{\star * \star}$ & 122.236 \\
\hline Very high-level Users & $12.576^{* * *}$ & 0.946 & $1396.81^{\star * *}$ & 311.933 \\
\hline
\end{tabular}

Note: ${ }^{* *}$ Indicates a significant level at $1 \%$.

outcome means of log gross margin are 9.3, 9.4, 9.5, 11.0 and 13.2 respectively for sorghum agrienterprises in non-users, low-level users, mid-level users, Highlevel users and very high-level users innovation users.

On the other hand, the average potential outcome of total sorghum harvested for the different innovation users using IPWRA was $845 \mathrm{Kgs}$, $989 \mathrm{Kgs}, 1265 \mathrm{Kgs}$, $1674 \mathrm{Kgs}$ and $1493 \mathrm{Kgs}$ for non-user, low-level users, mid-level users, high-level users and very high-level users respectively. This result hypothesises a positive relationship between the number of product and market innovation used by agrienterprises and competitiveness. Both the gross margin of the farm and productivity increases with an additional number of innovations used on the 
farm. The results are in line with studies of (Läpple \& Throne, 2019) and (Makate et al., 2019) among others. Despite the positive increase, there is a reduction in both the log gross margin and farm productivity of the very high-level users. This was expected since the effect of innovation on competitiveness at the latter stage is tempered by saturation effects hence the decrease (Woo \& Magee, 2017) in the competitive level of the agrienterprises.

\subsubsection{Average Treatment Effects for the Treatment Estimators}

Table 11 presents pairwise treatment effect for each group across treatment effects estimators. The double robust estimators, (AIPW) were discussed since they are consistently unbiased parameter even when the treatment or outcome model is not correctly specified (Linden et al., 2016). If so, RA and IPW average treatment effect coefficients were found to be the same in terms of sign and direction of the effects.

The results show that for agrienterprises in the control group (Non-Users), there would be an increase in gross margin by $18 \%$ if they decide to move to high-level users and $45 \%$ if they decide to move to the highest level very high-level users at $1 \%$ significant level. Moreover, the result depicted that if sorghum agrienterprises with low-level users would add innovation and move to high-level users their gross margin would increase by $17 \%$ and by $43 \%$ if they were to move to very high-level users. Agrienterprises at mid-level users would have their gross margin increased by $15 \%$ and $41 \%$ if they add more innovation to high-level users and very high-level users respectively. Lastly, agrienterprises in high-level users would increase their gross margin by $23 \%$ if they are to add innovation in their farms and move to the very high-level user at a $5 \%$ level of significance.

Furthermore, farm productivity increase as agrienterprises adds innovation and move from one level to the other as shown in Table 3. The results show a positive significant change in non-users and low-level users of innovation. There was a significant change at a $1 \%$ level of significance if an agrienterprises decides to move from low level to mid-level, its farm productivity would increase by $51 \%$, it would further increase by $76 \%$ if low-level users decide to move to high-level. Moreover, if low-level users choose to move to a very high level it would increase by $67 \%$ at a $10 \%$ level of significance. For Low-level users, the result depicted an increase of $28 \%$ if low-level innovation user chooses to move to mid-level users at $10 \%$ level of significance, and $50 \%$ increase if they decide to changes to high-level users at $5 \%$.

The findings point to the importance of production and market innovations by sorghum agrienterprises in the informal economy in Tharaka County on their performances. The results indicated that there is a positive causal correlation between innovation and competitiveness of an agrienterprises (gross margins and farm productivity). Agriprenuers could be benefiting more as they move to the high level (number of innovations used in the farm). Therefore, production and market innovations play a role in running and agrienterprises since it helps 
Table 11. Treatment effects estimates across treatment effects estimators.

\begin{tabular}{|c|c|c|c|c|}
\hline \multirow{2}{*}{ Pairwise treatment effects } & \multicolumn{2}{|c|}{ Log Gross Margin } & \multicolumn{2}{|c|}{ Farm productivity } \\
\hline & (ATE) & RSE & ATE & RSE \\
\hline \multicolumn{5}{|l|}{$R A$} \\
\hline Non-user $\rightarrow$ Low Level Users & 0.024 & 0.019 & 0.127 & 0.140 \\
\hline Non-user $\rightarrow$ Mid-Level Users & $0.039^{* \star}$ & 0.019 & $0.449^{* *}$ & 0.189 \\
\hline Non-user $\rightarrow$ High Level Users & $0.183^{* \star *}$ & 0.024 & $0.684^{* * *}$ & 0.220 \\
\hline Non-user $\rightarrow$ Very High Level Users & $0.369^{* * *}$ & 0.106 & 0.602 & 0.387 \\
\hline Low Level Users $\rightarrow$ Mid-Level Users & 0.015 & 0.011 & $0.285^{\star *}$ & 0.141 \\
\hline Low Level Users $\rightarrow$ High Level Users & $0.155^{\star * *}$ & 0.015 & $0.494^{* * *}$ & 0.163 \\
\hline Low Level Users $\rightarrow$ Very high Level Users & $0.337^{\star \star}$ & 0.101 & 0.421 & 0.333 \\
\hline Mid-Level Users $\rightarrow$ High Level Users & 0.138 & 0.015 & 0.163 & 0.137 \\
\hline Mid-Level Users $\rightarrow$ Very High Level Users & $0.318^{\star * \star}$ & 0.099 & 0.106 & 0.262 \\
\hline High Level Users $\rightarrow$ Very High-Level Users & $0.158^{\star * *}$ & 0.087 & -0.049 & 0.227 \\
\hline \multicolumn{5}{|l|}{ IPW } \\
\hline Non-user $\rightarrow$ Low Level Users & 0.012 & 0.014 & 0.099 & 0.131 \\
\hline Non-user $\rightarrow$ Mid-Level Users & $0.031^{\star *}$ & 0.015 & $0.359^{* *}$ & 0.160 \\
\hline Non-user $\rightarrow$ High Level Users & $0.118^{* * *}$ & 0.019 & $0.818^{* * *}$ & 0.223 \\
\hline Non-user $\rightarrow$ Very High Level Users & $0.101^{\star * *}$ & 0.014 & $0.610^{* * *}$ & 0.179 \\
\hline Low Level Users $\rightarrow$ Mid-Level Users & 0.019 & 0.012 & $0.237^{\star}$ & 0.126 \\
\hline Low Level Users $\rightarrow$ High Level Users & $0.104^{* * *}$ & 0.016 & $0.654^{* * *}$ & 0.172 \\
\hline Low Level Users $\rightarrow$ Very high Level Users & $0.087^{* * *}$ & 0.011 & $0.465^{* * *}$ & 0.136 \\
\hline Mid-Level Users $\rightarrow$ High Level Users & $0.084^{* * *}$ & 0.016 & $0.338^{* *}$ & 0.135 \\
\hline Mid-Level Users $\rightarrow$ Very High Level Users & $0.067^{\star * *}$ & 0.012 & $0.185^{\star}$ & 0.110 \\
\hline High Level Users $\rightarrow$ Very High-Level Users & -0.015 & 0.014 & -0.114 & 0.083 \\
\hline \multicolumn{5}{|l|}{ IPWRA } \\
\hline Non-user $\rightarrow$ Low Level Users & 0.025 & 0.023 & 0.265 & 0.167 \\
\hline Non-user $\rightarrow$ Mid-Level Users & 0.033 & 0.024 & $0.504^{* *}$ & 0.223 \\
\hline Non-user $\rightarrow$ High Level Users & $0.180^{* * *}$ & 0.031 & $1.279^{* *}$ & 0.499 \\
\hline Non-user $\rightarrow$ Very High Level Users & $0.456^{* * *}$ & 0.170 & 0.741 & 0.508 \\
\hline Low Level Users $\rightarrow$ Mid-Level Users & 0.023 & 0.015 & $0.564^{* *}$ & 0.232 \\
\hline Low Level Users $\rightarrow$ High Level Users & $0.266^{* * *}$ & 0.037 & 1.257 & 0.798 \\
\hline Low Level Users $\rightarrow$ Very high Level Users & $0.488^{* * *}$ & 0.163 & 0.510 & 0.383 \\
\hline Mid-Level Users $\rightarrow$ High Level Users & $0.238^{\star * *}$ & 0.037 & 0.443 & 0.533 \\
\hline Mid-Level Users $\rightarrow$ Very High Level Users & $0.454^{* * *}$ & 0.157 & -0.035 & 0.272 \\
\hline High Level Users $\rightarrow$ Very High-Level Users & 0.175 & 0.132 & -0.331 & 0.290 \\
\hline \multicolumn{5}{|l|}{$A I P W$} \\
\hline Non-user $\rightarrow$ Low Level Users & 0.012 & 0.020 & 0.178 & 0.142 \\
\hline
\end{tabular}




\begin{tabular}{lcccc} 
Continued & & & & \\
\hline Non-user $\rightarrow$ Mid-Level Users & 0.027 & 0.020 & $0.507^{* * *}$ & 0.192 \\
Non-user $\rightarrow$ High Level Users & $0.181^{* * *}$ & 0.031 & $0.763^{* * *}$ & 0.263 \\
Non-user $\rightarrow$ Very High Level Users & $0.451^{* * *}$ & 0.145 & $0.673^{*}$ & 0.399 \\
Low Level Users $\rightarrow$ Mid-Level Users & 0.015 & 0.011 & $0.279^{*}$ & 0.145 \\
Low Level Users $\rightarrow$ High Level Users & $0.167^{* * *}$ & 0.024 & $0.497^{* *}$ & 0.204 \\
Low Level Users $\rightarrow$ Very high Level Users & $0.433^{* * *}$ & 0141 & 0.421 & 0.331 \\
Mid-Level Users $\rightarrow$ High Level Users & $0.149^{* * *}$ & 0.023 & 0.170 & 0.171 \\
Mid-Level Users $\rightarrow$ Very High Level Users & $0.412^{* * *}$ & 0.139 & 0.111 & 0.263 \\
High Level Users $\rightarrow$ Very High-Level Users & $0.229^{* *}$ & 0.123 & -0.051 & 0.237
\end{tabular}

Note: ${ }^{* *},{ }^{* *},{ }^{*}$, indicates significant level at $1 \%, 5 \%$ and $10 \%$ level, respectively.

in improve agrienterprises' profitability, productivity, and thus helps achieve a competitive advantage (Tul-Krzyszczuk \& Jankowski, 2019; Makate et al., 2019; Läpple \& Throne, 2019; Gumbochuma, 2017) in the change agricultural economy. Hence, the small scale agrienterprises should be encouraged and provider with institutional support such as good infrastructure road network and information access, capacity building of group and formal or informal contract agreement with buyers or agents to aid the competitive level.

\section{Conclusion}

The vital findings are that the increased number of products and the use of market innovations have the potential to alleviate agrienterprises competitive level in terms of gross margin and farm productivity. Hence, production and market innovation play a key role in the competitiveness of sorghum agrienterprises. Agrienterprises should be sensitized to incorporate various production and market innovations in their farms to increase competitiveness. This could be done in groups by extension providers and media platforms like radio, television, and newspaper to increase awareness. The number of innovations incorporated in the farm to matter in term of output either the gross margin or productivity, but it also depends on the capacity of the agrienterprises. Hence the extension providers should advise the agrienterprises accordingly.

\section{Acknowledgements}

This article is part of the MSc thesis supported by Egerton University. We would like to thank sorghum agripreneurs at Tharaka county for their cooperation during the data collection period. We appreciate the Department of Agricultural Economics and Agribusiness Management, Egerton Univesity.

\section{Conflicts of Interest}

The authors declare no conflict of interest regarding the publication of this paper.

\section{References}

Adegbembo, T., Awodele, O., \& Oke, A. (2020). A Principal Component Analysis of Know- 
ledge Management Success Factors in Construction Firms in Nigeria. Journal of Construction Project Management and Innovation, 10, 42-54. https://doi.org/10.36615/jcpmi.v10i1.346

Adeyemo, T., Okoruwa, V., \& Akinyosoye, V. (2018). Estimating Causal Effects of CassavaBased Value-Webs on Smallholders' Welfare: A Multivalued Treatment Approach. International Association of Agricultural Economists 2018 Conference, Vancouver, British Columbia, 28 July-2 August 2018.

Ahmad, H., \& Halim, H. (2017). Determining Sample Size for Research Activities. Selangor Business Review, 20-34.

Aziz, N. N. A., \& Samad, S. (2016). Innovation and Competitive Advantage: Moderating Effects of Firm Age in Foods Manufacturing SMEs in Malaysia. Procedia Economics and Finance, 35, 256-266. https://doi.org/10.1016/S2212-5671(16)00032-0

Bamgbade, J. A., Kamaruddeen, A. M., \& Nawi, M. N. M. (2017). Malaysian Construction Firms' Social Sustainability via Organizational Innovativeness and Government Support: The Mediating Role of Market Culture. Journal of Cleaner Production, 154, 114-124. https://doi.org/10.1016/j.jclepro.2017.03.187

Bhupendra, K. V., \& Sangle, S. (2015). What Drives the Successful Implementation of Pollution Prevention and Cleaner Technology Strategy? The Role of Innovative Capability. Journal of Environmental Management, 155, 184-192. https://doi.org/10.1016/j.jenvman.2015.03.032

Carayannis, E., \& Grigoroudis, E. (2016). Quadruple Innovation Helix and Smart Specialization: Knowledge Production and National Competitiveness. Journal of the National Research University Higher School of Economics, 10, 31-42.

https://doi.org/10.17323/1995-459x.2016.1.31.42 https://foresight-journal.hse.ru/en/2016-10-1/178892561.html

Dar, W. D., \& Laxmipathi, G. C. L. (2013). Declining Agricultural Productivity and Global Food Security. Journal of Crop Improvement, 27, 242-254. https://doi.org/10.1080/15427528.2011.653097

Distanont, A., \& Khongmalai, O. (2018). The Role of Innovation in Creating a Competitive Advantage. Kasetsart Journal of Social Sciences, 41, 1-7. https://doi.org/10.1016/j.kjss.2018.07.009

Donkor, E., Mathews, N., \& Ogundeji, A. (2018). Efficiency of Rice Farming in Ghana: Policy Implication for Rice Sector Development. African Development Review, 30, 149-161. https://doi.org/10.1111/1467-8268.12320

Esparcia, J. (2013). Innovation and the Networks in Rural Areas: An Analysis from European Innovative Projects. Journal of Rural Studies, 34, 1-14.

https://doi.org/10.1016/j.jrurstud.2013.12.004

Funk, M., Westreich, D., Wiesen, C., Stürmer, T., Brookhart, M., \& Davidian, M. (2011). Doubly Robust Estimation of Causal Effects. American Journal of Epidemiology, 173, 761-767. https://doi.org/10.1093/aje/kwq439

Gaiha, R., \& Mathur, S. (2019). Agricultural Research, Technology and Nutrition in SubSaharan Africa. In R. Jha, Ed., Hunger and Malnutrition as Major Challenges of the 21 st Century (pp. 291-371), World Scientific Publishing, Singapore. https://doi.org/10.1142/9789813239913_0010

Gamage, H. K., Tetu, S. G., Chong, R. W., Ashton, J., Packer, N. H., \& Paulsen, I. T. (2017). Cereal Products Derived from Wheat, Sorghum, Rice and Oats Alter the Infant Gut Microbiota in Vitro. Scientific Reports, 7, Article No. 14312. https://doi.org/10.1038/s41598-017-14707-z

Gandhi, S. K., Sachdeva, A., \& Gupta, A. (2019). Impact of Service Quality on Satisfaction and Loyalty at Manufacturer-Distributor Dyad: Insights from Indian SMEs. Journal of 
Advances in Management Research, 16, 91-122. https://doi.org/10.1108/JAMR-12-2017-0120

Godfray, H. C. J., Beddington, J. R., Crute, I. R., Haddad, L., Lawrence, D., Muir, J. F., \& Toulmin, C. (2010). Food Security: The Challenge of Feeding 9 Billion People. Science, 327, 812-818. https://doi.org/10.1126/science.1185383

Government of Kenya (GoK) (2017). Implementation of the Agenda 2030 for Sustainable Development in Kenya. Nairobi: Government of Kenya.

Grebmer, K. V., Ruel, M. T., Menon, P., Nestorova, B., Olofinbiyi, T., Fritschel, H. et al. (2010). 2010 Global Hunger Index. The Challenge of Hunger, Focus on the Crisis of Child Undernutrition. Washington DC: International Food Policy Research Institute.

Gumbochuma, J. (2017). The Status and Impact of Technology Transfer and Innovation on the Productivity and Competitiveness of Small-Scale Agro-Processing Businesses in Mashonaland Central (Zimbabwe) and Free State (South Africa). Doctoral Dissertation, Free State: Central University of Technology.

Gupta, S., Malhotra, N. K., Czinkota, M., \& Foroudi, P. (2016). Marketing Innovation: A Consequence of Competitiveness. Journal of Business Research, 69, 5671-5681.

https://doi.org/10.1016/j.jbusres.2016.02.042

Jerop, R., Dannenberg, P., George Owuor, G., \& Mshenga, P. (2018). Factors Affecting the Adoption of Agricultural Innovations on Underutilized Cereals: The Case of Finger Millet among Smallholder Farmers in Kenya. African Journal of Agricultural Research, 13, 1888-1900. https://doi.org/10.5897/AJAR2018.13357

Karimi, R., Nair, R. M., Ledesma, D., Mutisya, D. L., \& Muthoni, L. (2019). Performance and Participatory Evaluation of Green Gram Genotypes in the Semi-Arid Environments of Eastern Kenya. East African Agricultural and Forestry Journal, 83, 119-136. https://doi.org/10.1080/00128325.2019.1599491

Kenya National Bureau of Statistics (KNBS) (2019). Economic Survey. Nairobi: Government of Kenya Printing Press.

Läpple, D., \& Thorne, F. (2019) The Role of Innovation in Farm Economic Sustainability: Generalised Propensity Score Evidence from Irish Dairy Farms. Journal of Agricultural Economics, 70, 178-197. https://doi.org/10.1111/1477-9552.12282

Lechner, M. (2001). Identification and Estimation of Causal Effects of Multiple Treatments under the Conditional Independence Assumption. In M. Lechner, \& F. Pfeiffer (Eds.), Econometric Evaluation of Labour Market Policy (pp. 43-58). Heidelberg: Physical/Springer. https://doi.org/10.1007/978-3-642-57615-7_3

Lin, R. J., Chen, R. H., \& Chiu, K. K. S. (2010). Customer Relationship Management and Innovation Capability: An Empirical Study. Industrial Management and Data Systems, 110, 111-133. https://doi.org/10.1108/02635571011008434

Linden, A., Uysal, S. D., Ryan, A., \& Adams J, L. (2016). Estimating Causal Effects for Multivalued Treatments: A Comparison of Approaches. Statistics in Medicine, 35, 534-552. https://doi.org/10.1002/sim.6768

Makate, C., Makate, M., Siziba, S., \& Sadomba, Z. (2019). The Impact of Innovation on the Performance of Small-to-Medium Informal Metal-Trade Enterprises in Zimbabwe. Cogent Business \& Management, 6, Article ID: 1625095.

https://doi.org/10.1080/23311975.2019.1625095

Micheels, E. T., \& Gow, H. R. (2015). The Effect of Market Orientation on Learning, Innovativeness, and Performance in Primary Agriculture. Canadian Journal of Agricultural Economics, 63, 209-233. https://doi.org/10.1111/cjag.12047

Mmbando, F. E., \& Baiyegunhi, L. J. (2016). Socio-Economic and Institutional Factors Influencing Adoption of Improved Maize Varieties in Hai District, Tanzania. Journal of Human Ecology, 53, 49-56. https://doi.org/10.1080/09709274.2016.11906955 
Mutsvangwa-Sammie, E. P., Manzungu, E., \& Siziba, S. (2017). Profiles of Innovators in a Semi-Arid Smallholder Agricultural Environment in Southwest Zimbabwe. Physics and Chemistry of the Earth, Parts $A / B / C, 100,325-335$.

https://doi.org/10.1016/j.pce.2016.09.002

Mwangi, M., \& Kariuki, S. (2015). Factors Determining the Adoption of New Agricultural Technology by Small Scale Farmers in Developing Countries. Journal of Economics and Sustainable Development, 6, 208-216.

Nenonen, S., Storbacka, K., \& Windahl, C. (2019). Capabilities for Market-Shaping: Triggering and Facilitating Increased Value Creation. Journal of the Academy of Marketing Science, 47, 617-639. https://doi.org/10.1007/s11747-019-00643-Z

Ogada, M. J., Nyangena, W., \& Yesuf, M (2010). Production Risk and Farm Technology Adoption in Rain-Fed Semi-Arid Lands of Kenya. African Journal of Agricultural and Resource Economics, 4, 159-174.

Okello, D. O. (2017). Effect of ICT Use on Performance of Agri-Enterprises. A Case of Smallholder Pineapple Farmers in Kiambu County, Kenya. Masters Dissertation, Njoro: Egerton University.

Olsson, A., Wadell, C., Odenrick, P., \& Bergendahl, M. (2010). An Action Learning Method for Increased Innovation Capability in Organizations. Action Learning: Research and Practice, 7, 167-179. https://doi.org/10.1080/14767333.2010.488328

Onyango, A. O. (2016). Finger Millet: Food Security Crop in the Arid and Semi-Arid Lands (ASALs) of Kenya. World Environment, 6, 62-70.

Orr, A., Mwema, C., \& Mulinge, W. (2013). The Value Chain for Sorghum Beer in Kenya. Paper No. 16, Telangana: International Crops Research Institute for the Semi-Arid Tropics (ICRISAT).

Orr, A., Mwema, C., Gierend, A., \& Nedumaran, S. (2016). Sorghum and Millets in Eastern and Southern Africa: Facts, Trends and Outlook. Telangana: International Crops Research Institute for the Semi-Arid Tropics (ICRISAT).

Sen, S., \& Antara, N. (2018). Influencing Factors to Stay Off-Campus Living by Students. SSRN No. 3598509. https://doi.org/10.2139/ssrn.3598509

Singh, N., Sinha, N., \& Liébana-Cabanillas, F. (2020). Determining Factors in the Adoption and Recommendation of Mobile Wallet Services in India: Analysis of the Effect of Innovativeness, Stress to Use and Social Influence. International Journal of Information Management, 50, 191-205. https://doi.org/10.1016/j.ijinfomgt.2019.05.022

Titilola, M. B., Marangu, D., \& Olayide, O. E. (2018). Assessment of Impact of Sorghum for Multiple Uses (SMU) Value Chain Project on Smallholder Farmers in Eastern Kenya. African Journal of Sustainable Development, 8, 109-129.

Tul-Krzyszczuk, A., \& Jankowski, P. (2019). The Impact of Innovation on the Global Competitiveness of Polish Meat and Dairy Enterprises. Problems of World Agriculture, 19, 120-132. https://doi.org/10.22630/PRS.2019.19.1.11

Wabwile, V. K., Ingasia, O. A., \& Langat, J. K. (2016). Effect of the Improved Sweet Potato Varieties on Household Food Security: Empirical Evidence from Kenya. 2016 th International Conference, Addis Ababa, 23-26 September 2016, Article No. 246916.

Woo, J., \& Magee, C. L. (2017). Exploring the Relationship between Technological Improvement and Innovation Diffusion: An Empirical Test. arXiv preprint, arXiv: 1704.03597.

Zhang, Y., Schnell, P., Song, C., Huang, B., \& Lu, B. (2021). Subgroup Causal Effect Identification and Estimation via Matching Tree. Computational Statistics \& Data Analysis, 159, Article ID: 107188. https://doi.org/10.1016/j.csda.2021.107188 
Appendix 1: Estimated Probabilities of Assignment to Treatment Units

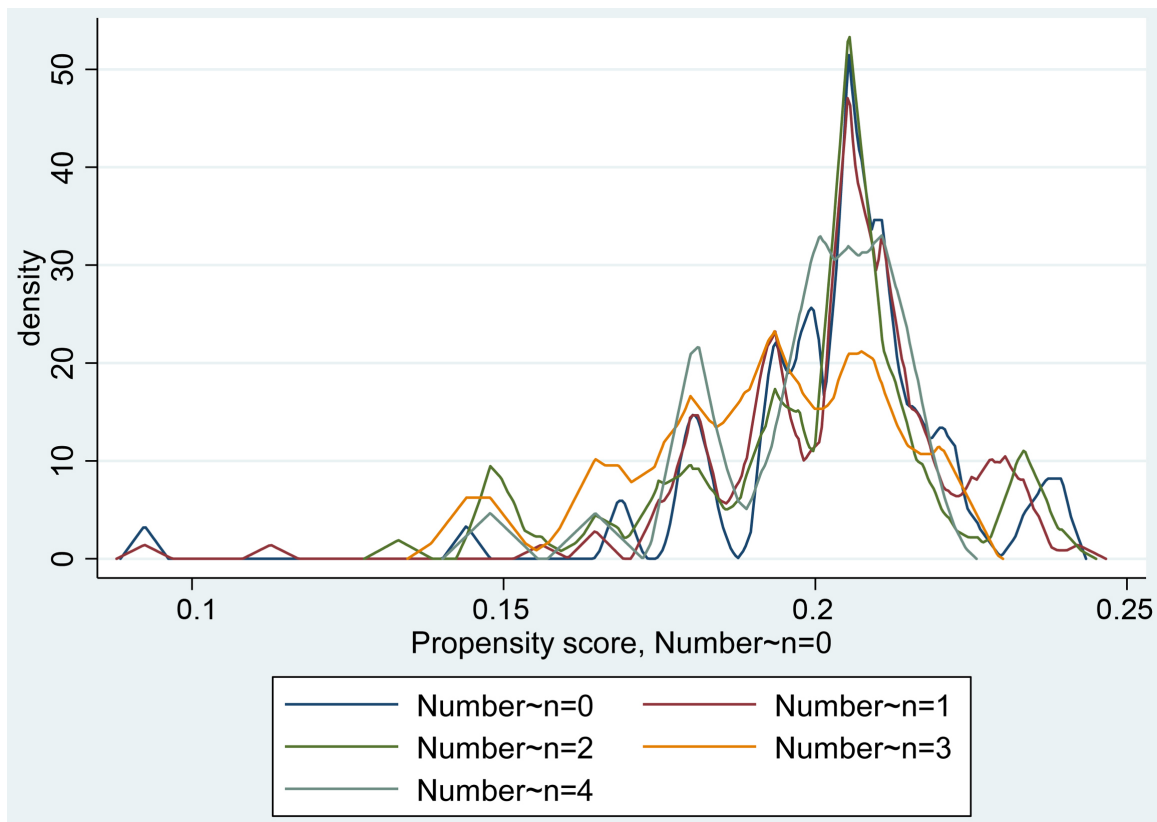

